\title{
成形加工の元気な仲間
}

\section{フッ素樹脂の成形加工と高品質保持管理技術 一日本インテグリス株式会社米沢工場一}

\section{1.はじめに}

日本インテグリス株式会社の本社所在地は東京であるも のの，その製造拠点は山形県米沢市にある。同社は米国イ ンテグリスの日本法人という位置づけではあるが，近年誘 致された企業ではない. 1980 年代から当地に日本の製造 拠点を構え，30 年近く事業を継続してきた特徽をもつ. このような視点から，その間に培われた成形加工，製造， 品質保持管理技術について今回取材させていただいた。同 社名であるインテグリスとは健全, 堅固, 卓越, 完全など を意味するラテン語 “integritas”に由来する. 取材を通 して至る所にその様子がうかがえた。

\section{2. 沿革}

インテグリス社は米国マサチューセッツ州ボストン近郊 のビレリカに本社を構え, 日本を含め世界 10 力国で 2, 200 名の従業員を抱えるグローバルな企業である. しかし，同 社は分社合併等によりその姿を変えつつ, 現在に至った経 緯がある。

日本法人である日本インテグリスとしても同様の形態を たどっており, 現在の形態としての歴史は比較的浅い. 2006 年 1 月に日本マイクロリスとインテグリスジャパンが合併 して誕生したのが日本インテグリスである。日本マイクロ リスはミリポア社の分社によりマイクロエレクトロニクス 事業部が継承, 独立した企業でフィルター関連の事業を手
がけてきた.一方，インテグリスジャパンはフロロウエア 社を前身とし，フッ素樹脂成形品の製造を手がけてき た. 1980 年代に両社はそれぞれ山形県米沢市に製造拠点 を設け，基盤を築いてきた．現在は一つの企業となり最先 端の半導体産業に貢献する世界最大のマテリアル・プロセ ス維持管理企業として実績を重ねている.

現在日本インテグリスでは，各種液体・気体用のフィル ターをはじめ, ポンプ, 半導体ウェー八搬送出荷容器等の 製造を行っている. 製造拠点である米沢工場では従業員 150 人のうち，製造に 120 人程度が携わっている.

\section{3.フッ素樹脂などの特徴ある成形加工}

日本インテグリスの主力商品の一つが各種産業用フィル ターである，液体用，気体用に多種多様な製品を製造して いるが，その中でも半導体製造現場等での用途においては 耐薬品性, 洗浄性に優れたフッ素樹脂製のものが要求され る. 図 1 及び 2 に同社の成形加工品及びフィルター製品の 写真を示した. カートリッジフィルター及びハウジングが 一体となったディスポーザブルフィルターである。 それら に加え，フィルターを接続するバルブ，継ぎ手，チューブ などの製品も製造している.PFA（テトラフルオロエチ レンパーフルオロアルキルビニールエーテル共重合体）の 成形技術，さらにそれらをフィルター等の製品に組立加工 する接合技術など高い技術が集約されている。図 3 に成形 現場の様子を示す.
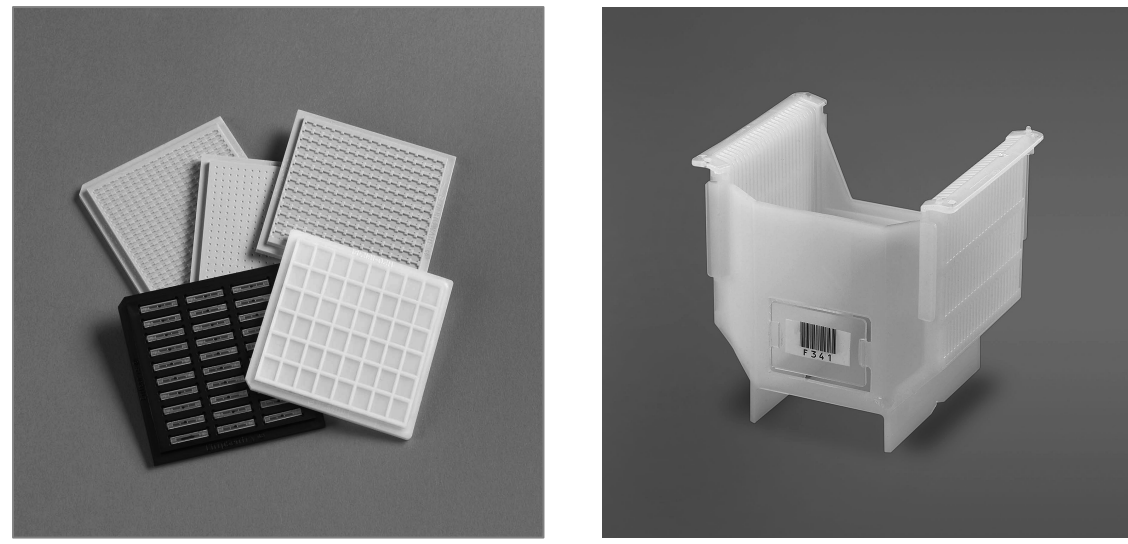

図 1 同社の成形加工品

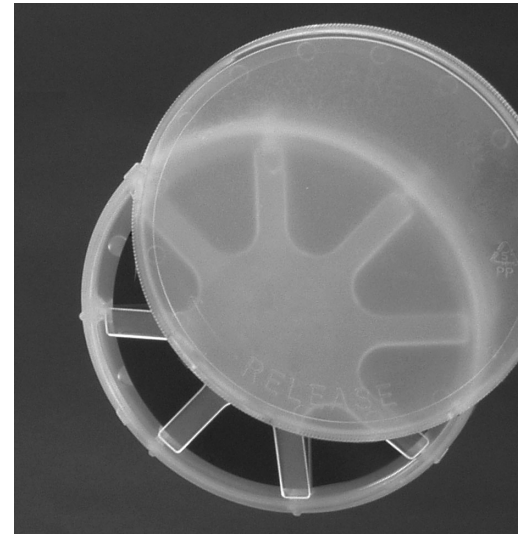

成形加工 第 22 巻 第 1 号 2010 

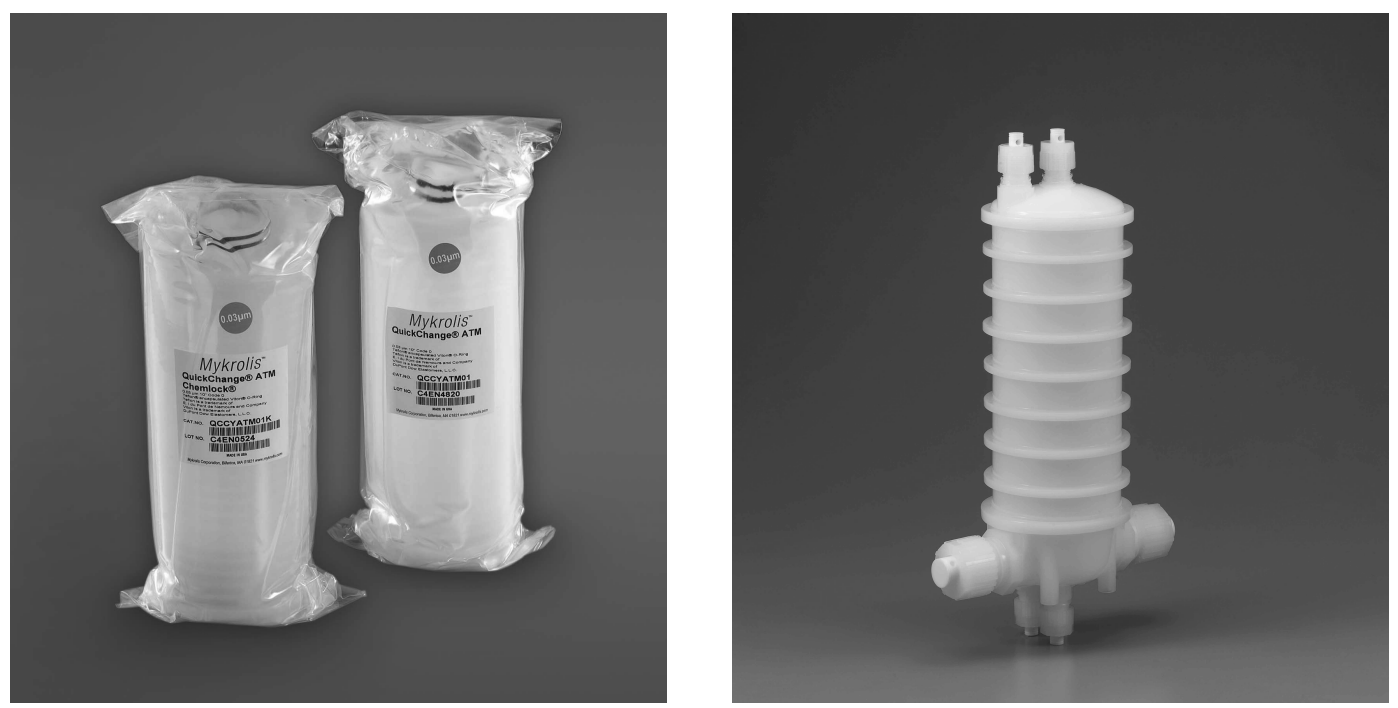

図 2 フィルター等フッ素樹脂成形品

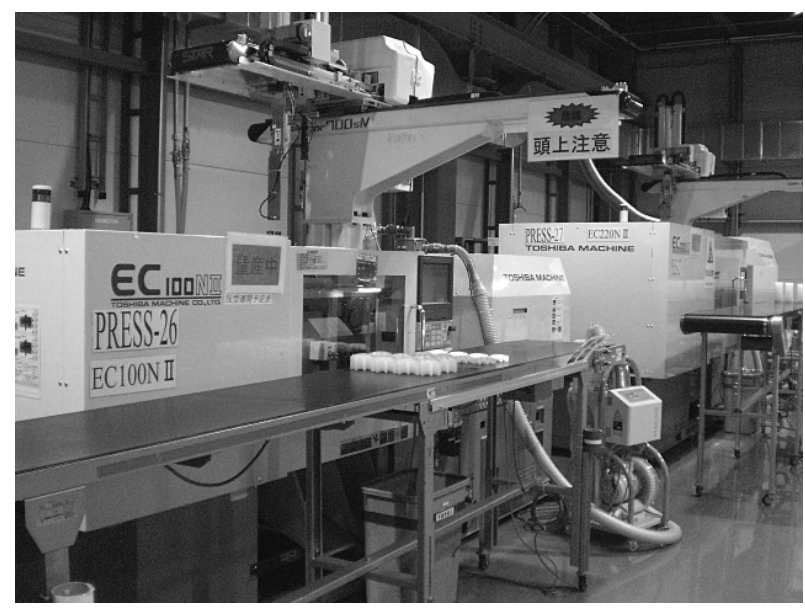

図 3 成形加工現場

また図 4 に示したポリカーボネート製の $300 \mathrm{~mm}$ ウェー 八出荷容器は, 型締力 1,000 トンの射出成形機を所有し, 同社内で成形，製造している．図 5 に実際に成形をしてい る様子を示す。識別用バーコードが印刷されたフィルムを インサートして成形している.さらに成形品のサイズが $300 \mathrm{~mm}$ と大型なため, 取り出しロボットをコンパクトに 設計している.このように同社はフッ素樹脂という特殊な 高分子材料の成形加工から超大型の射出成形までを手がけ, 付加価值性の高い製品を製造している。

\section{4. 高い生産・品質管理技術}

同社のもう一つの特徴は生産品質管理技術にある. 全て の製品を高品質に安定供給するため, 継続的改善 (CI, Continuous Improvement）活動や品質管理体制の確立に積極 的に取り組んでいる。CI 活動についてはリーン生産方式 やシックスシグマ $(6 \sigma)$ と呼ばれる手法を取り入れてい る.リーン生産方式とは米国で体系化された方式である. いわゆるトヨタ生産方式を一般化させた生産管理手法であ り, 無駄を徹底的になくしていく管理手法である. 一方, シックスシグマとは統計的手法であり, 製品に生じる品質 のばらつきをなくす手法である。こちらも米国で体系化さ れた方法であるが，日本の品質管理（QC）を元にしたと



図4 1, 000 トンの射出成形機で成形されたポリカー ボネート製の $300 \mathrm{~mm}$ ウェーハ出荷容器

いわれている。このような CI 活動について特徴的なこと は，同社はかつて日本の企業で培われ，アメリカで体系化 された手法を，日本のみならず世界へ展開し品質管理を 行っていることである. 同社内にはその研修の様子が揭示 されていた。（図 6) リーン生産方式やシックスシグマに 精通した米国人講師が合宿方式で「リーン・シグマ・チャ ンピオン・トレーニング」という研修を行っているとのこ とである。

また米沢工場では全社員が業務のムダ・ムリ・ムラ (3 Mu) をなくす社員主導の取り組みがある. $3 \mathrm{Mu}$ 報告 書という書類を通じて行うものであるが, 独立した事務局 で処理し，その効果を最大に生かすシステムをとっている.

\section{5.おわりに}

同社はいわゆる外資系の誘致企業である．しかし，日本 に製造拠点を構え 30 年近くが経過し，世界的視点から半 


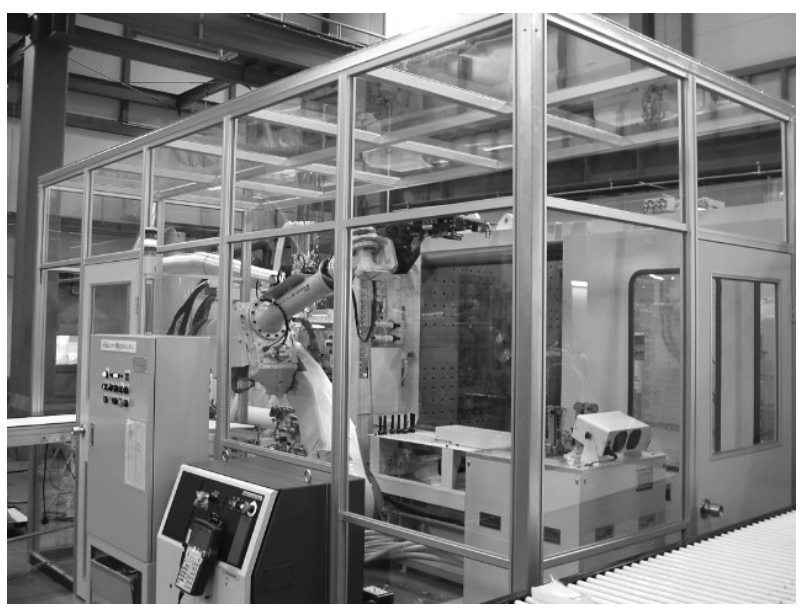

図 $5300 \mathrm{~mm}$ ウェーハ出荷容器を 1,000 トンの 射出成形機で成形している. 取り出しロ ボットにもエ夫がある.

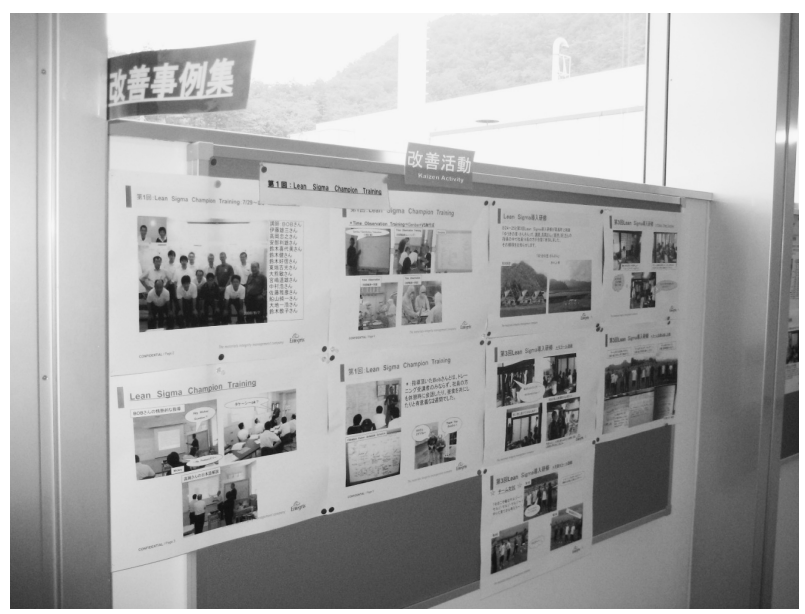

図 6 継続的改善活動の一環で行われている「リーン・ シグマ・チャンピオン・トレーニング」の様子

導体産業，また同社グループ内においても確固たる基盤を 築いている。これは特色のある生産・品質管理体制を敷き， 特色あるプラスチック成形加工製品を生産するシステムが なし得た結果であろう。このような外資系企業が山形県の

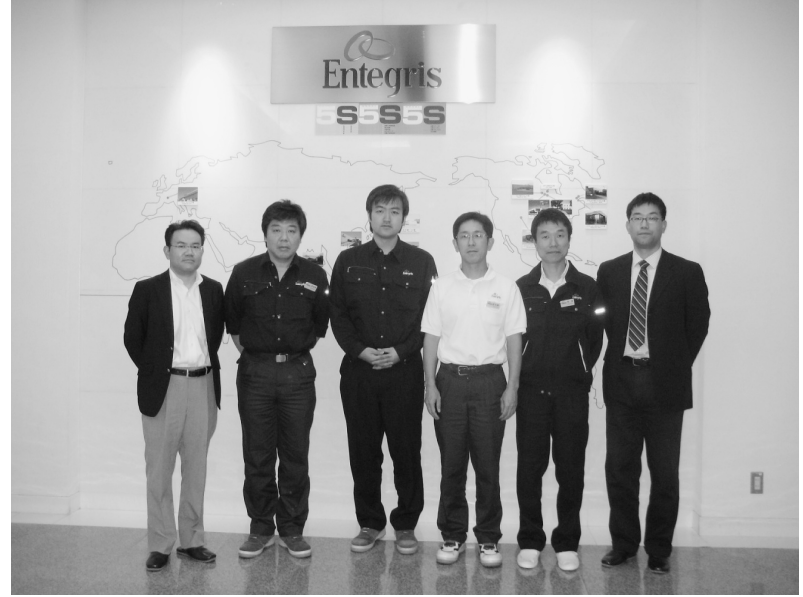

図 7 日本インテグリス株式会社の方々と記念撮影 左から伊藤, 波多野成氏, 船山純一氏，鈴木喜代美 氏，押野圭三氏，宮田

一都市に拠点を構え，世界に優れた製品を供給し続けるに あたり，様々な困難を乗り越えてきたことは容易に推測で きる，今回の取材ではその核心，秘訣にまで迫ることはで きなかったが，地方都市で力強く活躍する企業のあり方に ついての一端をみることができたと思う．

最後にご多忙中にもかかわらず，本取材にご協力を賜り ました同社取締役伊藤雄三氏，宮嶋道雄氏，鈴木喜代美氏， 波多野成氏，押野圭三氏，船山純一氏に深く感謝致します。 (取材：本誌編集委員 伊藤浩志, 宮田剣（記)）

\section{(連絡先)}

日本インテグリス株式会社

米沢事業所 ウェハーセル 部門責任者 鈴木喜代美 于 992-1128 山形県米沢市八幡原 2-4736-3

電話０238-28-1611

FAX 0238-29-0028

e-mail kiyomi_suzuki@entegris.com http ://www.entegris.com/nihon 